\title{
A STUDY ON THE CHANGES OF PERSPECTIVE ON DISCRIMINATION AMONG IN-GROUP PEERS IN ROMANIAN SCHOOLS
}

\author{
Luiza Enachi-Vasluianu \\ University of Bucharest, Romania \\ Flavia Mălureanu \\ University of Bucharest, Romania
}

\begin{abstract}
Even if most of modern schools today value diversity, promote multiculturalism, enforce antiharassment policies, they still confront with discrimination and its negative effects. Irrespective of teachers' efforts to stop this phenomenon, discrimination will always manifest within classrooms through less or more aggressive forms as children have a tendency to reject what is different as a form of self-protection.

The specific focus of this article is on different types of discrimination of in-group peers at gymnasium and high school. The two levels of school were selected as at these ages (11-15 for gymnasium and 15-19 for high school) students possess the cognitive and emotional capacities to deal with such experiences. The investigations performed led to the identification of discrimination based on social categories, financial conditions, ethnicity (mutual discrimination between Romanians and Gypsies/Roma), environment of provenance (rural versus urban areas), physical or mental disability, religion (the sample involved in the research are mostly orthodox, but there are also confessions with differences in religious beliefs and practice).

The present study has as starting point a research done in 2007, which put under the lens the main types of discrimination existing within classroom groups of peers from gymnasium and high school. The study was resumed in 2019 using the same criteria of investigation. We compared the two series of data and the results reflect the differences of students' perspectives on the same types of discrimination investigated at 12 years distance in time. As research methods we used the investigation based on questionnaire, the conversation and the systematic observation. The data gathered were processed using the SPSS analysis. The results of the research could be used to establish strategies of antidiscrimination based on respect and tolerance for diversity.
\end{abstract}

Keywords: discrimination, ethnicity, financial conditions, in-group peers, social categories.

\section{Introduction}

Discrimination refers to any differentiation, exclusion, restriction or preference on a series of criteria mentioned by the law (Portal legislativ, 2006; Consiliul Național pentru Combaterea Discriminării din România, 2019). Among 
the criteria established according to the Romanian Laws are: ethnicity, language, religion, social category, personal beliefs, gender, sexual orientation, physical or mental disability, chronic noncontagious disease as well as any other criterion which leads to restriction, lack of recognition, use or exercise, in terms of equality, of the human rights and of the fundamental liberties in the political, economic, social, cultural or any other field of public life. Discrimination means explicit negative treatment or less favourable treatment for individuals or groups of people in similar contexts. Although in any democratic society discrimination is sanctioned, unfortunately, in real life discrimination still occurs. This happens because discrimination is based on stereotypes and prejudices that people are not always aware of (Actored, 2012).

In schools discrimination has negative impact on students: at individual level: low school performances, lack of motivation, sense of guilt, low selfesteem, stress, depression etc.; at group level: deficient communication, situations of conflict, encouragement of stereotypes, unproductive competition, delay in developing maturity of thinking (Mihăiescu, Putineanu, \& Rîureanu, 2018). Students who deal with the humiliating experience of discrimination are affected in a multitude of forms. As a rule, they are reluctant to approach this problem in public even if, for some of them, discrimination has become a daily problem. Our paper aims to present a concrete situation of discrimination among the students from the schools included in the study so this information could help teachers identify more easily the different types of discrimination of in-group peers and helps them take the necessary measures. At the same time, the paper presents a change in students' opinions on the same types of discrimination investigated at 12 years distance in time.

\section{Literature review}

Discrimination based on social category starts from the hierarchical differences in society determined by three variables: economic (occupation, income, fortune), interaction (personal authority, social connections) and political (power). The concept of social category is connected to domination, power and conflict (Ferreol, 1998). Discrimination is, in this context, differential, unfair treatment towards persons because of their affiliation to a certain social group (Mihăiescu et al., 2018). In the same context, in schools children who come from families with good, respected professional position often discriminate those whose families have lower social positions.

Financial conditions are tightly connected to the concept of social category. As a source of discrimination it is often met in classrooms, as students involved in the study stated. Image is important for the gymnasium and high school students as, in their opinion, it gets or imposes respect from colleagues. It is 
rendered through brand clothes, latest models of mobile phones, allowance, the cars used for transportation to and away from school. Children who come from families with poor financial background often become the target of their rich colleagues as they are ridiculed for their clothes, their less expensive personal objects etc.

At social level, discrimination generates a vicious circle in which different forms of discrimination lead to a pileup of situations in which a group is disadvantaged by another, to the increase of social distance between individuals, to the reinforcement of negative stereotypes, all of which contributing to further increase of the probability of discrimination (Proiect Dezvoltarea programelor de studii universitare şi extinderea oportunităţilor de învăţare pentru studenţi şi piaţa muncii, 2013). One of the criteria of discrimination with such mapping is that of environment of provenance of the students. Many students from rural areas in close proximity to towns are enrolled into gymnasium schools in towns. Parents think that education in urban schools is better than that in the rural schools and as such their children are provided with more chances of getting into a good high school. Furthermore, the enrolling into high school, the upper school level, is done according to the means obtained in the national exam taken after gymnasium graduation so that many children from rural environment get to attend town high schools. Irrespective of the school level, children who live in urban areas display adverse attitudes manifested through negative labelling and exclusion of the ones who come from villages.

Discrimination based on ethnic criterion represents a form of exclusion of a group because its members share a series of attributes derived from the peculiarities of their traditional culture that make them be regarded as inferior or less desirable in society (Mihăiescu et al., 2018). In Romania, although there are prejudices against Jews, Turkish, and Hungarians as some of the country's ethnic minorities, the group that seems to suffer more from discrimination is Roma. Research done by authorities and non-governmental organizations show that Rom identity is a social stigma as Gypsies (controversial term because it is quite often used with negative connotation) are associated with indolence, dirt and crime (Marin \& Csonta, 2013). On the other hand, prejudices persist as many Roma refuse to get involved in social activities, refuse to get active on the labour market or to allow their children to attend school. However, in the recent years, thanks to the efforts of non-governmental organizations and Romanian authorities there has been some progress regarding a change of perspective on education. Schools throughout the country have organized formal and non-formal educational activities for the Rom adults and children and Roma had a rather good attendance. Teachers do their best to encourage Roma children to attend school in order to contribute, at least partially, to the dissolution of the vicious circle generated by lack of education, integration on the labour market and poverty 
(Neagu, Dowden, \& Macovei, 2010). In the area where the research was conducted the minority population is Roma. According to their customs, their children (especially girls) do not attend school for more than 5 to 6 years as they marry young. On the other hand, the majority population places great importance on the role of education for their children's future social and professional success and expect their children to undergo the whole system of education. The differences of culture between the two ethnicities lead to mutual distrust and disregard. Parents' attitude is mimicked by children. Both Romanians and Roma discriminate each other in classrooms.

Discrimination of people with physical or mental disabilities is based on fact that the standard of a "normal life" is not to have a disability of any kind. The accent is laid on disability, on what a person cannot do, instead of what the respective person can do. The effect of this perspective is segregation of these persons, especially those with mental disabilities. In Romania children with disabilities go to public schools. Although there is some reluctance towards them, teachers, as well as students make efforts to integrate them. The discussions in focus-groups showed that their discrimination is not caused by their disabilities, but because they become turbulent and interrupt the didactic activities (Neagu et al., 2010).

Discrimination based on religious criterion means the exclusion or rejection of a person or a group of persons because of their religious affiliation. In today's society, marked by numerous global conflicts, which encompass also religious reasons, this type of discrimination, is ever more present and its effects get more serious. In Romanian society religious tolerance is rather high and discrimination based on this criterion is contextual. In the group involved in our study religious discrimination makes reference to possible discrimination of people of religious affiliations other than those of the majority population, which is Orthodox Christian in our country (Neagu et al., 2010).

\section{Methodology of research}

The present study uses as starting point a research done in 2007, which put under the lens the main types of discrimination existing within classroom groups of peers from gymnasium and high school. The identification of such elements was based on theoretical background and focus-group discussions with students from both school levels. The study was resumed in 2019 using the same criteria of investigation: social categories, financial conditions, ethnicity, environment of provenance, physical or mental disability, religion. Descriptive analyses of the selected items were realized in order to determine a hierarchy in the two school levels, gymnasium and high school. The data provided in the two studies showed 
if there had been any changes of perspective on discrimination within classroom peers at twelve years distance in time.

The participants. The sample for research was made of 200 students from Vrancea County, Romania, 100 from gymnasium and 100 from high school. The two levels of school were selected as at these ages (11-15 for gymnasium and 15-19 for high school) students possess the cognitive and emotional capacities to deal with such experiences. They were involved in the research on a voluntary basis.

The instrument of research. As research methods we used the investigation based on questionnaire, the conversation and the systematic observation. The respondents had to choose one of the following options of a five-step scale: (1) to a very low extent, (2) to a low extent, (3) to an average extent, (4) to a large extent, (5) to a very large extent.

\section{Findings and results}

For the descriptive analyses, we used SPSS software, the t-test for the independent samples.

Table 1 Means and Standard Deviation of Criteria of Discrimination in School

\begin{tabular}{|c|c|c|}
\hline Items of & Gymnasium 2007 & Gymnasium 2019 \\
\hline Social categories & $4.62(0.733)$ & $4.68(0.614)$ \\
\hline Financial conditions & $4.08(1.322)$ & $4.74(1.178)$ \\
\hline Ethnicity & $4.16(0.682)$ & $3.82(0.995)$ \\
\hline Environment of provenance & $4.82(0.438)$ & $3.92(1.307)$ \\
\hline Physical or mental disability & $4.74(1.126)$ & $4.02(0.892)$ \\
\hline Religion & $3.86(1.525)$ & $3.76(1.080)$ \\
\hline
\end{tabular}

Source: Autors 2007, 2019

Table 2 Description of Hierarchy of Criteria of Discrimination in School

\begin{tabular}{|c|c|c|}
\hline Rank & Gymnasium 2007 & Gymnasium 2019 \\
\hline 1. & Environment of provenance & Financial conditions \\
\hline 2. & Physical or mental disability & Social categories \\
\hline 3. & Social categories & Physical or mental disability \\
\hline 4. & Ethnicity & Environment of provenance \\
\hline 5. & Financial conditions & Ethnicity \\
\hline 6. & Religion & Religion \\
\hline
\end{tabular}

Source: Autors 2007, 2019

For the 2007 study on the indicators of discrimination among in-group peers in Romanian gymnasium schools the top three ranks were for environment of provenance $(m=4.82)$, physical or mental disability $(m=4.74)$, social categories 
$(\mathrm{m}=4.62)$. Things changed 12 years later. Thus, the top three ranks for the same school level are for financial conditions $(\mathrm{m}=4.74)$, social conditions $(\mathrm{m}=4.68)$, physical or mental disability $(\mathrm{m}=4.02)$. Since 2007 Romania joined EU which allowed access to various cultures and commercial diversification on our market. As a result children have been exposed to many temptations from clothing to informational technology. In the recent years children have associated image with trendy brand clothes, expensive school requisites, phones and tablets. Children who cannot afford such items become the target of their peers' discrimination. The social conditions in this context make reference to parents' professions and position in the social hierarchy. This indicator is tightly connected to the previous one, that is good social position equals financial security.

For physical or mental disability indicator there is quite a large difference between the means from 2007 study $(\mathrm{m}=4.74)$ and the 2019 study $(\mathrm{m}=4.02)$. This is due to, we believe, the inclusion policies developed over the years, which diminished teachers' and peers' reluctance to the presence of children with physical or mental disabilities in classrooms. On the other hand, the third rank in the 2019 hierarchy shows that there are still prejudices related to their slowing down the didactic process. The mean above 4 for this item shows that it is still perceived as a major criterion of discrimination, as it was 12 years earlier.

We used the $\mathrm{T}$ test for the independent groups to determine the differences of the opinions regarding the criteria of discrimination among in-group peers in Romanian schools. The significance level was set to 0.05. Starting from the significant differences from a statistical point of view among students' appreciations, we could state the relevance of the criteria of discrimination among in-group peers in Romanian schools in gymnasium school level in 2007 and in 2019. The analyses showed significant differences for three items (environment of provenance, physical or mental disability, financial conditions, $\mathrm{p}<0.05$ ). We registered statistically insignificant differences for three items (social category, ethnicity, religion), indicating the convergence of opinions of the students from gymnasium school level.

For gymnasium, starting from the statistically significant differences, the place of provenance ranked first $(\mathrm{m}=4.82)$ in the 2007 study, whereas it ranked $4^{\text {th }}$ in the 2019 study $(m=3.92)$. Students involved in the study explained that in the recent years many children from rural areas have been transferred to schools from the urban areas as parents consider that schools in town have better teachers and as such their children have more chances to acquire good education. 
SOCIETY. INTEGRATION. EDUCATION

Proceedings of the International Scientific Conference. Volume III, May $22^{\text {th }}-23^{\text {th }}$, 2020. 143-151

Table 3 Means and Standard Deviation of Criteria of Discrimination in School

\begin{tabular}{|c|c|c|}
\hline Items of & High school 2007 & High school 2019 \\
\hline Social categories & $4.46(0.613)$ & $4.58(0.538)$ \\
\hline Financial conditions & $4.94(0.935)$ & $4.86(0.756)$ \\
\hline Ethnicity & $4.66(1.118)$ & $3.72(1.070)$ \\
\hline Environment of provenance & $3.94(0.856)$ & $3.64(0.995)$ \\
\hline Physical or mental disability & $3.52(0.838)$ & $3.32(0.960)$ \\
\hline Religion & $3.50(0.678)$ & $4.28(1.102)$ \\
\hline
\end{tabular}

Source: Autors 2007, 2019

Table 4 Description of Hierarchy of Criteria of Discrimination in School

\begin{tabular}{|c|c|c|}
\hline Rank & High school 2007 & High school 2019 \\
\hline 1. & Financial conditions & Financial conditions \\
\hline 2. & Ethnicity & Social categories \\
\hline 3. & Social categories & Religion \\
\hline 4. & Environment of provenance & Ethnicity \\
\hline 5. & Physical or mental disability & Environment of provenance \\
\hline 6. & Religion & Physical or mental disability \\
\hline
\end{tabular}

Source: Autors 2007, 2019

For the 2007 study on the indicators of discrimination among in-group peers in Romanian high schools the top three ranks belonged to financial conditions $(\mathrm{m}=4.94)$, ethnicity $(\mathrm{m}=4.66)$, social category $(\mathrm{m}=4.46)$. In 2019 the ranking changed: financial $(\mathrm{m}=4.86)$, social conditions $(\mathrm{m}=4.58)$, religion $(\mathrm{m}=4.28)$. The first rank for both studies is for financial conditions, which demonstrates teenagers' interest for the benefits they can get for their image from their parents' financial situation. This is the reason for which teenagers with poor financial background are often discriminated. Ethnicity as source of discrimination moved from the second rank in $2007(\mathrm{~m}=4.66)$ down to the fourth rank in 2019 $(\mathrm{m}=3.72)$. The explanation lies in the fact that over the last 12 years there have been developed social and school programmes that targeted Gypsies/Roma population (as the minority population in the area where the research was done). The increased attendance of the Roma in schools made some of the children of both ethnicities more tolerant, whereas others maintained their racist opinions.

The second rank for the 2019 study is for social conditions. The causes are the same as in gymnasium, according to the students participating in the study. Although ranked last in the 2007 research, religion as source of discrimination moved up to the third rank in the 2019 research. The emphasis laid by the media on the specifics of different religions and the association of terrorism and intransigence with certain religions made this topic become source of discrimination in schools. 
Enachi-Vasluianu \& Mălureanu, 2020. A Study on the Changes of Perspective on Discrimination Among in-Group Peers in Romanian Schools

At high school level, statistically significant differences were registered for 2 items: ethnicity and religion. For ethnicity the mean was higher in 2007 $(\mathrm{m}=4.66)$ than in $2019(\mathrm{~m}=3.72)$, whereas for religion the mean was lower in $2007(\mathrm{~m}=3.50)$ than in $2019(\mathrm{~m}=4.28)$.

\section{Conclusions}

Our study indicates the main sources of discrimination among in-group peers in the Romanian school, at gymnasium and high school levels. It also emphasizes a change of perspective on discrimination among students over a period of 12 years. 2007, the year when the first study was conducted, is the year when Romania joined EU. It is the year that triggered different changes that affected all aspects of social, economic, cultural and political life. Thus, in 2007, according to the opinions of the students' involved in the research, environment of provenance, physical or mental disability, social categories were perceived as main sources of discrimination among in-group peers for gymnasium level, whereas financial conditions, ethnicity, social categories were considered as main sources of discrimination for high school. Over time there have been many changes that can also be seen in the alteration of people's perspective on different negative issues of social life. Thus in 2019, according to the opinions of the students involved in the research, financial conditions, social categories, physical or mental disabilities were perceived as major sources of discrimination for gymnasium, whereas for high school, students acknowledged financial conditions, social categories and religion as main sources of discrimination among in-group peers.

Our study draws attention on the importance of good knowledge of the criteria of discrimination in classrooms and helps teachers prefigure the risks and the social and individual effects of discrimination. The data gathered might be of use for the teachers who should be able to adapt their classroom management strategies so that they could promote nondiscrimination achieved through tolerance and reinforcement of positive relationships within the group.

Moreover, the results of the study may be used as teaching materials in classrooms so as students can better grasp the concept of discrimination with its forms of manifestation, with its criteria and their identification in everyday life. In an interactive approach students could be provided with the opportunity to debate points of view on the matter, to develop role plays, all resulting in better awareness of this issue, in promoting tolerance and positive integration. Thus, if everyone participating in the didactic process is aware of the magnitude of discrimination, then efficient changes can be made to reach one of the global principles for human rights friendly schools: non-discrimination and inclusion (Amnesty International, 2012). 


\section{References}

Actored. (2012). Ghid de bune practici pentru aplicarea principiului nediscriminării în activitățile didactice. Retrieved from https: //www.actored.ro /file _comp /documente / ActorED_Ghid_de_bune_practici.pdf

Amnesty International. (2012). Becoming a human rightsfriendly school. A guide for schools around the world. London: Peter Benenson House.

Consiliul Naţional pentru Combaterea Discriminării din România. (2019). Profil [Datafile]. Retrieved from https://cncd.ro/profil

Enachi-Vasluianu, L., \& Mălureanu, F. (2007). A Study about discrimination. Not published.

Gilles Ferreol. (1998). Dicționar de sociologie. Iași: Polirom.

Marin, A., \& Csonta, A. (2013). Discrimination of Roma Communities. Romania National Report. București: NET KARD Project.

Mihăiescu, O., Putineanu, D., \& Rîureanu, C. (2018). Discriminarea pe înțelesul tuturor. București: Asociația pentru Incluziune Socială Proetnica.

Neagu, M., Dowden, G., \& Macovei, O. (2010). Respect pentru diversitate. București: British Council România.

Portal legislativ. (2006). Legea Nr. 324 [Datafile]. Retrieved from http://legislatie. just.ro/ Public/ Detalii DocumentAfis /73606

Proiect Dezvoltarea programelor de studii universitare şi extinderea oportunităţilor de învăţare pentru studenţi şi piaţa muncii. (2013). Discriminarea şi strategii antidiscriminatorii [Datafile]. Iași: Fundația solidaritate și speranță. Retrieved from http://dpus.usv.ro/docs/A6/A6.4_continut_discriminarea_si_strategii_antidicriminatoriifinal.pdf 